Pak. j. sci. ind. res. Ser. B: biol. sci. 2017 60(3) 168-175

\title{
Spider Diversity in Some Common Oilseed Crops in Central Punjab, Pakistan
}

\author{
Sobia Riaz **, Saima Kausara, Muhammad Mohsin', Aamir Mahmood Memonº, \\ Iram Maqsood ${ }^{c}$ and Muhammad Nadeem Abbas ${ }^{a}$ \\ ${ }^{a}$ Department of Zoology and Fisheries, University of Agriculture, Faisalabad, Pakistan \\ ${ }^{\mathrm{b}}$ College of Fisheries, Ocean University of China, Qingdao 266003, China \\ ${ }^{c}$ Northeast Agriculture University, Herbin, China
}

(received September 14, 2015; revised November 14, 2016; accepted December 13, 2016)

\begin{abstract}
Three commonly cultivated oilseed crops viz., soybean, sunflower and Indian mustard were sampled to compare density and diversity of spider at different developmental stages. This study was conducted at Ayub Agriculture Research Institute, Faisalabad, Pakistan. A total of 1210 spider individuals, 68 species and 5 families were sampled throughout the study period. The families showed different levels of association with the crops, like Lycosidae and Clubionidae were found commonly spread and highly abundant, whereas Philodromidae was only restricted to sunflower and locally rare. The Evippa sohani, Pardosa fletcheri, Evippa shivajii and Pardosa oakleyi were recorded most dominant and commonly spread spider species. Indian mustard constituted highest diversity of spider species followed by soybean and sunflower. Spider species diversity on the Indian mustard was significantly different from the sunflower. These predator species can play a major role to suppress devastating agricultural pests of oilseed crops, thereby enhance the crop yield.
\end{abstract}

Keywords: Araneae, agro-ecosystem, oil seed, ecology, agrochemicals, spider diversity

\section{Introduction}

The green revolution (1950-60) causes rapid loss of biodiversity by the adaption of monoculture system instead of polycluture (Abbas et al., 2014; Altieri, 1992). Almost 600 arthropod pest species seems to be affecting the yield of agricultural crops worldwide (Samways, 1997). In conventional agro-ecosystems, agrochemicals are heavily applied against insect pests that might be fatal to biocontrol agents, harmful to all levels of food chain, health risks of working with these chemicals, common people and further damage to environment quality (Pekar, 2005; Gamundi et al., 2001), whereas, biological pest control has several advantages over the chemical control as it is safe to handle, cost effective, provides long term management, self-perpetuating, no harms to the non-target organisms and environment friendly (Abbas et al., 2013; Abbas et al., 2012; Eisley and Hammond, 2007).

Over the last three decades, agriculture experiments have revealed that spiders species play a key role to suppress crop pest's populations. They are generalist terrestrial predators and potential bio-control agents compared to specialist predators (Wise, 1993). For instance, Fagan et al. (1998) documented that Lycosidae

*Author for correspondence; E-mail: riazsobia22@outlook.com and Linyphidae spider families can suppress variety of pests e.g., aphids (Aphidae), thrips (Thysanoptera) and leafhoppers (Cicadellidae), while Symondson et al. (2002) and Lang et al. (1999) confirmed the biocontrol activity and working independently on Delphacidae and Cicadellidae in field experiment. The spider diversity in agricultural ecosystem is significantly important to determine the influence of these predators on pest populations (Maloney et al., 2003). Furthermore, the more diverse spider populations warrant the better crop growth, thereby higher crop yield. Spider diversity is closely associated with features of plant community, landscape structure, kind of habitat and stages of plant growth in an agro-ecosystem (Foelix, 2010; Susilo, 2007; Suana et al., 2004).

Spider diversity being an important bio-control agent in agricultural ecosystem has attracted attention of the ecologists worldwide (Liu et al., 2003; Rypstra et al., 1999). Despite of its economic and ecological importance in agro-ecosystem, in Pakistan, only fragmentary work is available (Parveen et al., 2007; Mushtaq et al., 2005; Khan et al., 2001; Mushtaq and Qadir, 1997), particularly on oil crops (Bukhari et al., 2012; Musthaq et al., 2003; Ghafoor, 2002). Hence, the present study was conducted to investigate the diversity and abundance of spider fauna in soybean, sunflower and Indian mustard. 
Furthermore, the diversity between studied habitats were compared, that were located in Ayub Agriculture Research Institute, Faisalabad, Pakistan.

\section{Materials and Methods}

The present study was conducted in Ayub Agriculture Research Institute, district Faisalabad $\left(30^{\circ} 31.5 \mathrm{~N}\right.$ and $73^{\circ} 74 \mathrm{E}$ with an elevation of $184.4 \mathrm{~m}$ ), that lies in northeast of Punjab Pakistan. In Faisalabad, May, June, and July are the hottest months of the year with mean maximum temperature reaching $39^{\circ} \mathrm{C}$ and maximum daily temperature up to $49^{\circ} \mathrm{C}$. The monsoon rains mostly fall in July and August, which are the wettest months. December and January are the coldest months with a mean minimum temperature of $6{ }^{\circ} \mathrm{C}$ and occasionally passing below freezing (Mahmood-ul Hassan et al., 2010).

Soybean, sunflower and Indian mustard were sampled every 15 days interval and spider fauna was collected from different developmental stages of the studied crops. A total of 10 visits were made throughout the sampling period (January to May, 2014). An area of at least 4 hectares of these crops culture was selected randomly. Pitfall traps are commonly used in ecological studies. This is an absolute sampling technique to capture both nocturnal and diurnal active fauna. For this purpose, a glass jar comprised of $13 \mathrm{~cm}$ height and $6 \mathrm{~cm}$ in diameter was filled with $150 \mathrm{~mL}$ of $70 \%$ of ethyl alcohol. Two to five drops of $5 \%$ detergent was also added. A total 30 pitfall traps were installed, in diagonal pattern started from the margin of the fields. The traps were buried in soil with open end flushing with soil surface, whereas, shaking method was used to collect foliage spiders. For this purpose, branches of one plant at a time were shaken with an average 10 jerks for three times. A total of 50 plants were shaken from each site. Spider existed over a plant of sampling crops fall over white cloth, which were preserved in the polythene bags and were brought to Araneae Laboratory, Department of Zoology and Fisheries, University of Agriculture Faisalabad, Pakistan.

The collected specimens were washed with xylene and preserved into glass vials having a mixture of $1: 1$ ethyl alcohol and glycerin. All the spiders were identified up to the species level by using spider identification keys (Khalid, 2004; Barrion and Litsinger, 1995; Tikader, 1981).

Data was analyzed statistically to determine species diversity, species richness and evenness by using PAST statistical software. Microsoft Excel was used to construct different graphs according to analyzed data.

\section{Results and Discussion}

A total of 1210 specimens belonging to five families, 14 genera and 68 species were identified from oil producing crops. Soybean was found more abundant with 512 individuals followed by Indian mustard $(n=422)$ and sunflower $(\mathrm{n}=276)$.

Overall abundance of spiders. On average $51.2( \pm 9.58$ s.e) spider individuals were collected per trapping session (including pitfall and shaking methods) from the soybean and was found highly abundant, while Indian mustard $42.2( \pm 10.79$ s.e) stood second in abundance followed by sunflower 27.25 ( \pm 6.14 s.e). Only first two trapping sessions were recorded without spider individuals from these crops except Indian mustard. The abundance of spiders were varied in pitfall and shaking methods and further two sessions were without spiders in both sampling methods from soybean and sunflower, while one pitfall sessions from Indian mustard. Moreover, Indian mustard, sunflower and soybean habitats varied with the number of spider individuals (Fig. 1-2).

The abundance of spider is influenced by habitat structure, kind of vegetation and their complexity (Susilo, 2007; Suana et al., 2004). This indicates that spider species are host specific and reside on the specific kind of vegetations (Foelix, 1982). In the present study, abundance of spider individuals varied among studied crops that might be due to variable habitat complexity,



Fig 1. The dynamics of spider individuals of Indian mustard, sunflower and soybean in Shaking method. 


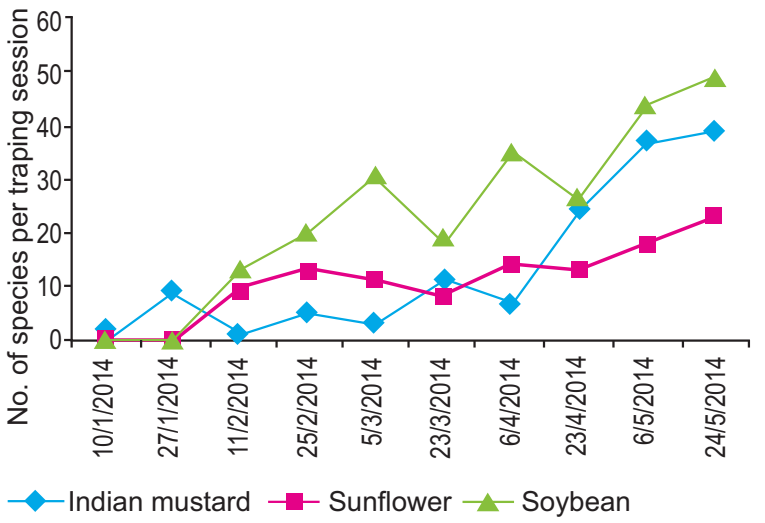

Fig 2. The dynamics of spider individuals of Indian mustard, sunflower and soybean in Pitfall method.

availability of food resources as well as association of spider individuals to certain crops. Similarly, Abbas et al. (2013) documented similar trends among the macroinvertebrates including spiders. They documented higher abundance of spiders on sugarcane weeds compared to wheat weeds. As sugarcane is a perennial crop it comprises of diverse vegetation, which provide breeding sites and feeding resources, in addition least disturbances either anthropogenic or farm management that makes the environment more suitable for the settlement of arthropods communities. Moreover, they noticed low arthropods communities including spiders abundance in the colder months like December and January, while higher in the warmer months (April, May etc) similar to present study. Likewise Ruby et al. (2011) documented similar results, while studying on the mustard, fodder, wheat and sugarcane crop in the central Punjab, Pakistan. Bukhari et al. (2012) explained high abundance in the warmer months in cotton fields. The maximum abundance of spider in the spring and summer season coincides with reproductive periods and the emergence of juveniles. Furthermore, the ground vegetation greatly grow, in this season that provides stable microhabitats, and shelter as well as a wide availability of prey for spiders. Method of collection also influences the diversity and abundance of insects. For instance, pitfall trapping is controversial in ecological studies due to several reasons like they are affected by physiological state and behaviour of animals, weather, density of vegetation and type of habitat and so on (Topping and Sunderland, 1992). Further, they are unable to reflect true picture of community composition and diversity, variation in trap ability and dilute the habitat effect. Irrespective of this, the method is extensively used in the ecological studies as it is least expensive method, monitoring is convenient and collection of wide array of species is possible.

Abundance of spider families. Lycosidae, Thomicidae, Chlubionide, Salticidae and Philodromidae families were recorded from the Indian mustard, sunflower and soybean of which Lycosidae and Clubionidae were common and found abundant in all studied crops. However, former was recorded highly dominant particularly in soybean. As these crops were adjacently located that might influence the movement of spider species among the studied crops, whereas, the family Philodromidae was only resident of sunflower (Table 1 and Fig. 3).

Overall Lycosidae formed almost $80 \%$ of spider fauna collected from oilseed crops and was found most abundant family followed by Thomisidae and Clubionidae, while Philodromidae $(0.58 \%)$ was found least abundant spider family (Table 1). Bukhari et al. (2012) found Lycosidae (57.39\%) the most dominant family. Further they also recorded Salticidae (25.59), Thomicidae $(6.50 \%)$ and clubionidae $(2.36 \%)$ in the cotton in district Gujranwala, Pakistan. Muthukumaravel et al. (2013) also documented similar findings while studying mangroves in India.

Table 1. Number of spider individuals per family and functional group (guilds) found in Indian mustard, sunflower and soybean Faisalabad district. HAM: Hunting - Ambushers; AHU: Active-Hunters; HRU: Hunting - Runners

\begin{tabular}{|c|c|c|c|c|c|c|}
\hline \multirow[b]{2}{*}{ Families } & \multirow[b]{2}{*}{ Guild } & \multicolumn{3}{|c|}{ Agricultural crops } & \multirow[t]{2}{*}{ Total } & \multirow[t]{2}{*}{ Percentage $\%$} \\
\hline & & Brassica juncea & Sunflower & Soybean & & \\
\hline Lycosidae & HRU & 290 & 185 & 496 & 971 & 80.25 \\
\hline Thomicidae & HAM & 51 & 61 & - & 112 & 9.26 \\
\hline Clubionidae & AHU & 77 & 19 & 16 & 112 & 9.26 \\
\hline Salticidae & HAM & 4 & 4 & - & 08 & 0.66 \\
\hline Philodromidae & HAM & - & 7 & - & 7 & 0.58 \\
\hline Total & & 422 & 276 & 512 & 1210 & 100.00 \\
\hline
\end{tabular}




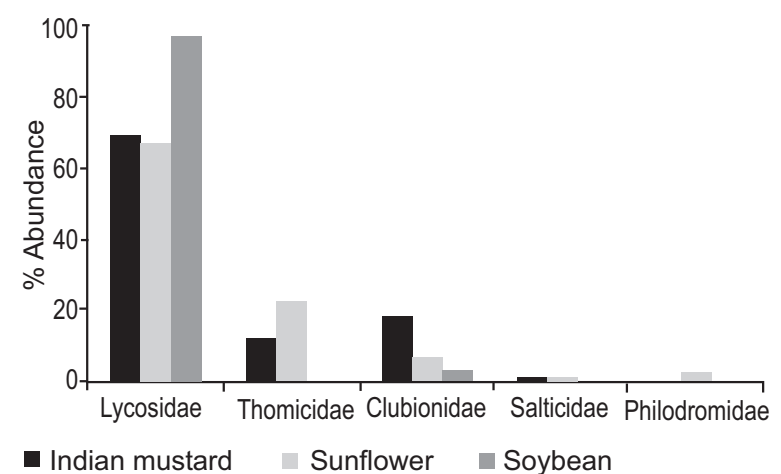

Fig 3. Percentage abundance for the spider families in Indian mustard, sunflower and soybean in Faisalabad, Pakistan.

Spider species richness and diversity. In this study, a total of 68 spider species were identified from the oil crops (Table 2). Thirty five of the 68 species were exclusively recorded only on single crop. Of which soybean had 18 spider species, while 10 spider species in sunflower and seven in Indian mustard were found exclusively. The more suitable explanation of this phenomenon, however, is the involvement of structural complexity of vegetation, which provides stable microhabitat and shelter. Johnson et al. (1996) also suggested relationship between ground vegetation and arthropod species.
Among the three habitats, spider species were greatly abundant in soybean. Forty two species were recorded distributing among Lycosidae and Clubionidae families. The family Lycosidae made almost $97 \%$ of total collected spider individuals. It constituted of four genera, of which Pardosa was remained highly abundant with 194 (39.11\%) individuals followed by Evippa 118 (23.05\%), and Lycosa 84 (16.40\%) were the least abundant. Pardosa oakleyi $(\mathrm{n}=40)$ was recorded highly abundant species followed by Evippa sohani $(\mathrm{n}=37)$, Evippa shivajii $(\mathrm{n}=33)$, Pardosa fletcheri $(\mathrm{n}=30)$, Pardosa sutherlandi $(\mathrm{n}=28)$, Pardosa timida $(\mathrm{n}=25)$, Lycosa wroughtoni $(\mathrm{n}=23)$, Hippasa olivacea and Hippasa partita $(n=19)$. These spider species contributed almost $50 \%$ to the total number of spider individuals collected from soybean. Whereas, Arctosa indicus, Evippa praelongipes, Pardosa birmanica, Clubiona maya, Clubiona pomoa, Pardosa chambaensis, Lycosa masteri, Lycosa chaperi, Evippa rajasthanea, Arctosa mulani were least abundant and collectively made almost $10 \%$ of the collected spiders. Furthermore 9\% spider species of the collected data were exclusively determined from the soybean.

Sunflower (37 spp) stood second in species richness among the three habitats, while third in total abundance $22.80 \%(\mathrm{n}=276)$. Only six spider species viz., Evippa shivajii $(\mathrm{n}=18)$, Evippa sohani $(\mathrm{n}=26)$, Lycosa wroughtoni ( $\mathrm{n}=17)$, Pardosa fletcheri $(\mathrm{n}=21)$, Pardosa

Table 2. Abundance of spider fauna recorded from Indian mustard, sunflower and soybean

\begin{tabular}{|c|c|c|c|c|c|c|c|}
\hline \multirow[b]{2}{*}{ Taxa } & \multicolumn{2}{|c|}{ Brassica juncea $(\%)$} & \multicolumn{2}{|c|}{ Sunflower (\%) } & \multicolumn{2}{|c|}{ Soybean (\%) } & \multirow[t]{2}{*}{ Total $(\%)$} \\
\hline & Pitfall & Shaking & Pitfall & Shaking & Pitfall & Shaking & \\
\hline \multicolumn{8}{|l|}{ Lycosidae } \\
\hline Arctosa indicus & - & - & - & - & - & $1(0.36)$ & $1(0.08)$ \\
\hline Arctosa mulani & - & - & - & - & - & $3(1.09)$ & $3(0.25)$ \\
\hline Evippa banarensis & $2(1.47)$ & $9(3.15)$ & - & - & $8(3.39)$ & $10(3.62)$ & $29(2.40)$ \\
\hline Evippa eltonica & $2(1.47)$ & $2(0.70)$ & - & - & - & - & $4(0.33)$ \\
\hline Evippa praelongipes & $1(0.74)$ & $8(2.80)$ & - & - & - & $2(0.72)$ & $11(0.91)$ \\
\hline Evippa rajasthanea & - & - & - & $1(0.60)$ & - & $3(1.09)$ & $4(0.33)$ \\
\hline Evippa rubiginosa & $4(2.94)$ & $11(3.85)$ & $1(0.91)$ & $1(0.60)$ & $9(3.81)$ & $7(2.54)$ & $33(2.73)$ \\
\hline Evippa shivajii & $4(2.94)$ & $5(1.75)$ & $6(5.45)$ & $12(7.23)$ & $16(6.78)$ & $17(6.16)$ & $60(4.96)$ \\
\hline Evippa sohani & $9(6.62)$ & $7(2.45)$ & $7(6.36)$ & $19(11.45)$ & $19(8.05)$ & $18(6.52)$ & $79(6.53)$ \\
\hline Evippa solanensis & $5(3.68)$ & $9(3.15)$ & $4(3.64)$ & $8(4.82)$ & - & $9(3.26)$ & $35(2.89)$ \\
\hline Hippasa greenalliae & $3(2.21)$ & $11(3.85)$ & - & - & $5(2.12)$ & $9(3.26)$ & $28(2.31)$ \\
\hline Hippasa himalayensis & $1(0.74)$ & $7(2.45)$ & $4(3.64)$ & $4(2.41)$ & $6(2.54)$ & $7(2.54)$ & $29(2.40)$ \\
\hline Hippasa loundesi & - & - & - & - & $6(2.54)$ & $2(0.72)$ & $8(0.66)$ \\
\hline Hippasa lycosina & - & - & - & - & $4(1.69)$ & $3(1.09)$ & $7(0.58)$ \\
\hline Hippasa madhuae & - & - & - & - & $3(1.27)$ & $2(0.72)$ & $5(0.41)$ \\
\hline
\end{tabular}




\begin{tabular}{|c|c|c|c|c|c|c|c|}
\hline Hippasa madraspatana & $2(1.47)$ & $13(4.55)$ & - & - & - & - & $15(1.24)$ \\
\hline Hippasa olivacea & $7(5.15)$ & $10(3.50)$ & $4(3.64)$ & $2(1.20)$ & $10(4.24)$ & $9(3.26)$ & $42(3.47)$ \\
\hline Hippasa partita & $3(2.21)$ & $17(5.94)$ & $1(0.91)$ & $4(2.41)$ & $9(3.81)$ & $10(3.62)$ & $44(3.64)$ \\
\hline Hippasa pisaurina & - & - & - & - & $2(0.85)$ & $3(1.09)$ & $5(0.41)$ \\
\hline Lycosa basiri & - & - & - & $2(1.20)$ & - & - & $2(0.17)$ \\
\hline Lycosa chaperi & - & - & - & - & $2(0.85)$ & $1(0.36)$ & $3(0.25)$ \\
\hline Lycosa choudhuryi & - & - & - & - & $3(1.27)$ & $3(1.09)$ & $6(0.50)$ \\
\hline Lycosa gobiaensis & $3(2.21)$ & $13(4.55)$ & $2(1.82)$ & $6(3.61)$ & $10(4.24)$ & $10(3.62)$ & $44(3.64)$ \\
\hline Lycosa madani & - & - & - & - & $3(1.27)$ & $3(1.09)$ & $6(0.50)$ \\
\hline Lycosa masteri & - & - & - & - & $1(0.42)$ & $2(0.72)$ & $3(0.25)$ \\
\hline Lycosa poonaensis & - & - & $5(4.55)$ & $4(2.41)$ & $12(5.08)$ & $11(3.99)$ & $32(2.64)$ \\
\hline Lycosa wroughtoni & $3(2.21)$ & $1(0.35)$ & $6(5.45)$ & $11(6.63)$ & $11(4.66)$ & $12(4.35)$ & $44(3.64)$ \\
\hline Pardosa birmanica & $7(5.15)$ & $17(5.94)$ & $2(1.82)$ & $1(0.60)$ & $1(0.42)$ & $1(0.36)$ & $29(2.40)$ \\
\hline Pardosa chambaensis & - & - & - & - & $2(0.85)$ & $2(0.72)$ & $4(0.33)$ \\
\hline Pardosa fletcheri & $2(1.47)$ & $11(3.85)$ & $3(2.73)$ & $18(10.84)$ & $15(6.36)$ & $15(5.43)$ & $64(5.29)$ \\
\hline Pardosa kupupa & $12(8.82)$ & $5(1.75)$ & - & - & $6(2.54)$ & $6(2.17)$ & $29(2.40)$ \\
\hline Pardosa lahorensis & - & - & $7(6.36)$ & $2(1.20)$ & $13(5.51)$ & - & $22(1.82)$ \\
\hline Pardosa leucopalpis & - & - & $2(1.82)$ & $18(10.84)$ & - & $13(4.71)$ & $33(2.73)$ \\
\hline Pardosa mukundi & - & - & - & - & $7(2.97)$ & $5(1.81)$ & $12(0.99)$ \\
\hline Pardosa mysorensis & $9(6.62)$ & $7(2.45)$ & $3(2.73)$ & $1(0.60)$ & $4(1.69)$ & $4(1.45)$ & $28(2.31)$ \\
\hline Pardosa oakleyi & $3(2.21)$ & $9(3.15)$ & $1(0.91)$ & $4(2.41)$ & $19(8.05)$ & $21(7.61)$ & $57(4.71)$ \\
\hline Pardosa sinensis & $7(5.15)$ & $10(3.50)$ & - & - & - & - & $17(1.40)$ \\
\hline Pardosa songosa & - & - & - & - & $4(1.69)$ & $3(1.09)$ & $7(0.58)$ \\
\hline Pardosa sumatrana & $9(6.62)$ & $10(3.50)$ & $7(6.36)$ & $2(1.20)$ & - & - & $28(2.31)$ \\
\hline Pardosa sutherlandi & - & - & - & - & $14(5.93)$ & $14(5.07)$ & $28(2.31)$ \\
\hline Pardosa timida & - & - & - & - & $12(5.08)$ & $13(4.71)$ & $25(2.07)$ \\
\hline $\begin{array}{l}\text { Trochosa infausta } \\
\text { Thomicidae }\end{array}$ & - & - & - & - & - & $6(2.17)$ & $6(0.50)$ \\
\hline Cupa kalawitana & $2(1.47)$ & - & $8(7.27)$ & $1(0.60)$ & - & - & $11(0.91)$ \\
\hline Camaricus florae & $3(2.21)$ & $11(3.85)$ & - & - & - & - & $14(1.16)$ \\
\hline Loxobates kawilus & $2(1.47)$ & $16(5.59)$ & - & - & - & - & $18(1.49)$ \\
\hline Misumena maputiyana & - & - & $5(4.55)$ & $2(1.20)$ & - & - & $7(0.58)$ \\
\hline Misumena menoka & - & - & $2(1.82)$ & $4(2.41)$ & - & - & $6(0.50)$ \\
\hline Misumena oblonga & - & - & $2(1.82)$ & $1(0.60)$ & - & - & $3(0.25)$ \\
\hline Misumena picta & - & - & $2(1.82)$ & $1(0.60)$ & - & - & $3(0.25)$ \\
\hline Misumena tapyasuka & - & - & $6(5.45)$ & $1(0.60)$ & - & - & $7(0.58)$ \\
\hline Misumenoides matinikus & - & - & $4(3.64)$ & $1(0.60)$ & - & - & $5(0.41)$ \\
\hline Thomisius italongus & $10(7.35)$ & - & $8(7.27)$ & $6(3.61)$ & - & - & $24(1.98)$ \\
\hline Thomisius & $3(2.21)$ & - & - & - & - & - & $3(0.25)$ \\
\hline $\begin{array}{l}\text { Thomisius okinawensis } \\
\text { Salticide }\end{array}$ & $4(2.94)$ & - & $2(1.82)$ & $5(3.01)$ & - & - & $11(0.91)$ \\
\hline Chalcotropis luceroi & $2(1.47)$ & $2(0.70)$ & - & $1(0.60)$ & - & - & $5(0.41)$ \\
\hline Plexippus paykulli & - & - & - & $1(0.60)$ & - & - & $1(0.08)$ \\
\hline Plexippus petersi & - & - & - & $2(1.20)$ & - & - & $2(0.17)$ \\
\hline Clubionidae & & & & & & & \\
\hline Clubiona analis & - & - & - & $1(0.60)$ & - & $3(1.09)$ & $4(0.33)$ \\
\hline Clubiona charleneae & $2(1.47)$ & $15(5.24)$ & - & - & - & - & $17(1.40)$ \\
\hline Clubiona comta & $2(1.47)$ & $12(4.20)$ & & $4(2.41)$ & - & - & $18(1.49)$ \\
\hline Clubiona drassodes & $2(1.47)$ & $5(1.75)$ & - & $6(3.61)$ & - & $6(2.17)$ & $19(1.57)$ \\
\hline Clubiona forcipa & - & - & - & - & - & $2(0.72)$ & $2(0.17)$ \\
\hline Clubiona hysgina & $2(1.47)$ & $2(0.70)$ & - & $7(4.22)$ & - & - & $11(0.91)$ \\
\hline Clubiona japonica & $3(2.21)$ & $15(5.24)$ & - & & - & - & $18(1.49)$ \\
\hline Clubiona maya & - & - & - & $1(0.60)$ & - & $2(0.72)$ & $3(0.25)$ \\
\hline Clubiona pomoa & - & - & - & - & - & $3(1.09)$ & $3(0.25)$ \\
\hline $\begin{array}{l}\text { Clubiona tikaderi } \\
\text { Philodromidae }\end{array}$ & $1(0.74)$ & $16(5.59)$ & - & - & - & - & $17(1.40)$ \\
\hline Philodromus medius & - & - & $6(5.45)$ & $1(0.60)$ & - & - & $7(0.58)$ \\
\hline Total & 136 & 286 & 110 & 166 & 236 & 276 & 1210 \\
\hline
\end{tabular}


leucopalpis $(\mathrm{n}=20)$ and Thomisius italongus $(\mathrm{n}=14)$ were found highly abundant that made up almost $43 \%$ to the spiders collected from sunflower. Remaining 31 spider species identified on this agroecosystem contributed $57 \%$, of which most of spider species only reached a least number (approximately 2\%). Interestingly, Philodromus medius $(6.05 \%)$ was the only single representative of the family and was exclusively resident on the sunflower.

Indian mustard contributed almost $35 \%(\mathrm{n}=422)$ to the total spider fauna with five families. Of which only Lycosidae made almost $70 \%$ of spider collected from Indian mustard. A total of 34 spider species were identified, of which, 11 species were recorded highly abundant, which added almost $50 \%$ of spider fauna. Pardosa birmanica $5.69 \%(\mathrm{n}=24), H$. partita $4.74 \%(\mathrm{n}=20)$, Pardosa sumatrana $4.50(\mathrm{n}=19)$, Clubiona japonica and Lycosa kawilus individually contributed $4.27 \%$ $(\mathrm{n}=18)$, while Pardosa kupupa, Pardosa sinensis, Clubiona tikaderi and Clubiona charleneae species individually added $4.03 \%(n=17)$. Further $3.79 \%(n=$ 16) was constituted by Lycosa gobiaensis and Pardosa mysorensis individually. Whereas, 10 species hardly reached the approximately to $1 \%$. Previously Bukhari et al. (2012) studied cotton fields in the Faisalabad district. They documented overall 21 spider species. Of which most dominant species e.g., Lycosa madani, Pardosa birmanica, Pardosa oakleyi, Lycosa kempi, Hippasa holmerae and Plexipus bengalensis were distributed in Lycosidae family like present study. Ghafoor and Mahmood (2011) captured 22 spider species from rice and sugarcane from district Gujranwala, Pakistan. However, the number of spider species remains low as compared to present work, which might be due to the difference in sampling method, number, kind and heterogeneity level of sampled agricultural crop. Whereas, Rodrigues et al. (2009) reported 85 spider species, belonging to 15 families from grassland, forest and rice agroecosystem in Brazil. This higher richness of spider species particularly in forest and grassland indicates that natural habitats still have least anthropogenic disturbance. Furthermore, availability of wide range of prey species, breeding and reproduction sites providing better opportunity to survive.

The overall spider richness, (S), eveness (E) and diversity $\left(\mathrm{H}^{\prime}\right)$ differed among these crops and significantly varied. However, non-significant difference was found between Indian mustard and soybean (Table 3). Whitmore et al. (2002) documented that increase in the level of disturbance in any environment lead to decrease in spider richness. Rodrigues et al. (2009) suggests that a terrestrial habitat with least perturbation particularly by anthropogenic activity has triggering impact to enhance the spider diversity in any habitat.

Guild comparison among spiders. Overall hunting runners were predominant $(80 \%)$ in the oil crops and remained abundant in all these environments. In soybean, hunting runners (approximately 96\%) were highly abundant, due to the large number of Lycosidae recorded, whereas, active hunters made a negligible portion (Fig. 4).

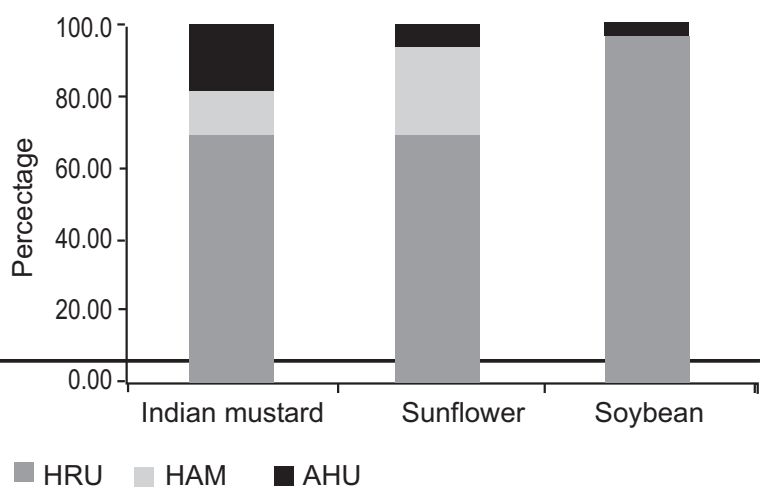

Fig 4. Spiders feeding guilds for the Indian mustard, sunflower and soybean crops in Faisalabad district. HAM: HuntingAmbushers; AHU: Active-Hunters; HRU: Hunting-Runners.

Table 3. Richness, diversity and evenness values for spider fauna recorded from Indian mustard juncea, sunflower and Soybean

\begin{tabular}{llllllllll}
\hline \hline Crops & $\mathrm{S}$ & $\mathrm{H}^{\prime}$ & $\mathrm{E}$ & $\mathrm{S}$ & $\mathrm{H}^{\prime}$ & $\mathrm{E}$ & $\mathrm{df}$ & $\mathrm{t}$-value & $\mathrm{p}$-value \\
\hline Brassica juncea/Sunflower & 34 & 3.405 & 0.88 & 37 & 3.311 & 0.74 & $>120$ & 2.39 & $0.017^{* *}$ \\
Brassica juncea/Soybean & 34 & 3.405 & 0.88 & 42 & 3.403 & 0.71 & $>120$ & 0.08 & $0.935 \mathrm{~ns}$ \\
Sunflower/Soybean & 37 & 3.311 & 0.74 & 42 & 3.403 & 0.71 & $>120$ & -2.09 & $0.036^{* *}$ \\
\hline \hline
\end{tabular}


These results coincide with the findings of Rimbing and Memah (2008). They found high abundance of Lycosidae, that constituted $34 \%$ to the collected predator species while studying the abundance of different predatory arthropods on soybean in North Minahasa. While Liljesthrom et al. (2002) reported 84\% Lycosidae during study on the agricultural crops. Agro-ecosystems are the largely disturbed sites by anthropogenic intervention that highly favour roving hunters over the webbuilder. Further, the absence of regular supporting structure for the web-builder in an agro-ecosystem might be responsible for their rarity (Muma and Muma, 1949).

\section{References}

Abbas, M.N., Rana, S.A., Mahmood-ul-Hassan, M., Rana, N., Kausar, S., Iqbal, M. 2014. Biodiversity and dynamics of macro-invertebrate populations in wheat-weeds agro-ecosystem of Punjab (Pakistan). Journal of Animal and Plant Sciences, 24: 1146-1156.

Abbas, M.N., Mahmood-ul-Hassan, M., Rana, S.A., Nawaz, K., Iqbal, R. 2013. The macroinvertebrate communities associated with some weed plants of sugarcane (Sacharum officinarum) and wheat (Triticum aestivum) crops of Faisalabad district (Pakistan). World Applied Science Journal, 28: 817-825.

Abbas, M.N., Rana, S.A., Khan, H.A., Khalil-urRehman. 2012. Status of trophic guild of invertebrates utilizing weeds of wheat and sugarcane fields of Faisalabad. Pakistan Journal of Agricultural Sciences, 49: 189-198.

Altieri, M. 1992. Biodiversidad, Agroecología y manejo de plagas. 162 pp. Cetal Ed., USA.

Barrion, A.T., Litsinger, J.A. 1995. Rice and Spiders of South and South East Asia. 701 pp. CAB-International Rice Research Institute, UK and IRRI, Philippines.

Bukhari, M., Naeem, M.M., Khalil-ur-Rehman, Andleeb, S. 2012. Occurrence and distribution of Araneid fauna trapped from cotton fields of district Faisalabad, Pakistan. World Applied Science Journal, 19: 714-718.

Eisley, B., Hammond, R. 2007. Control of insect pests of field crops. The Ohio State University Ext. Bulletin 545. Columbus, OH, USA.

Fagan, W.F., Hakim, A.L., Ariawan, H., Yuliyantiningsih, S. 1998. Interactions between biological control efforts and insecticide applications in tropical rice agro-ecosystems: The potential role of intraguild predation. Biology and Control, 13: 121-126.

Foelix, R.F. 2010. Biology of Spiders, $3^{\text {rd }}$ edition, Oxford: Oxford University Press, New York, USA.

Foelix, R.F. 1982. Biology of Spiders. Cambridge, 306 pp. Harvard University Press, vi+ MA, USA.

Gamundi, J., Molinari, A., Riart, S., Pochetino, E., Lenzi, L., Capelo, G. 2001. Evaluación de cultivos transgénicos Bt. Convenio INTA-MONSANTO Argentina S.A. $<$ http://www.inta.gov.ar/oliveros/ Acuerdos-Convenios. doc $>$. Acceso 25 agosto 2002.

Ghafoor, A., Mahmood, A. 2011. Population dynamics of Araneid fauna from district Gujranwala, Pakistan. The Journal of Animal and Plant Sciences, 21: 812-816.

Ghafoor, A. 2002. Taxonomic and some Ecological Studies of the Cursorial Spiders of Cotton Fields at Faisalabad. Ph.D. Thesis, Department of Zoology and Fisheries, University of Agriculture, Faisalabad, Pakistan, pp. 223-235.

Johnson, K.H., Vogt, K.A., Clark, H.J., Schmitz, O.J., Vogt, D.J. 1996. Biodiversity and the productivity and stability of ecosystems. Trends in Ecolology \& Evolution, 11: 372-377.

Khalid, M. 2004. Taxonomical Study of Foliage Spider Fauna of Punjab. Ph.D. Thesis, Department of Zoology and Fisheries, University of Agriculture, Faisalabad, Pakistan.

Khan, N., Masroor, J.I., Khalid, S. 2001. Species composition, distribution of cursorial spiders and their abundance, diversity and habitat in wheat. Journal of Biological Sciences, 1: 276-277.

Lang, A., Filser, J., Henschel, J.R. 1999. Predation by ground beetles and wolf spiders on herbivorous insects in a maize crop. Agriculture Ecosystems and Environment, 72: 189-199.

Liljesthrom, G., Minervino, E., Castro, D., González, A. 2002. La comunidad de arañas del cultivo de soja en la provincia de Buenos Aires, Argentina. Neotropical Entomology, 31: 197-210.

Liu, Y.F., Gu, D.X., Zhang, G.R. 2003. Studies on the diversity of spiders community in paddy ecosystems in Guangdong. Acta Arachnologica Sinica, 12: 27-31.

Maloney, D., Drummond, F.A., Alford, R. 2003. Spider predation in Agro-ecosystems: Can spiders effectively control pest populations? Technical Bulletin Maine Agricultural and Forest Experiment Station 190: iv +28 p. 
Mahmood-ul-Hassan, M., Gulraiz, T.L., Rana, S.A., Javid, A. 2010. The diet of Indian flying-foxes (Pteropus giganteus) in urban habitats of Pakistan. Acta Chiropterologica, 12: 341-347.

Muma, M.H., Muma, K.E. 1949. Studies on a population of prairie spiders. Ecology, 30: 485-503.

Musthaq, S., Ali, M.A., Riaz, M., Murtaza, A., Ahmad, S. 2005. Spider as insects natural enemies: evaluation of feeding niche of co-existing foliage species in cotton. Indus Cotton, 2: 193-204.

Musthaq, S., Beg, M.A., Aziz, S. 2003. Biodiversity and temporal varieties in the abundance of cursrial spiders of a cotton field at Faisalabad. Pakistan Journal of Zoology, 35: 125-131.

Mushtaq, S., Qader, A. 1999. Three new species of the genus Oxyopes (Araneae: Oxyopidae) from Pakistan. Pakistan Journal of Zoology, 31: 255-262.

Muthukumaravel, K., Amsath, A., Raja, R.B. 2013. A preliminary investigation of spider fauna in associated mangroves of Muthupet at Adirampattinam Coast, Tamil Nadu, India. International Journal of Pure and Applied Zoology, 1: 304-309.

Parveen, R., Khan, A., Mushtaq, S., Rana, S.A. 2007. A checklist of the spiders of the Punjab. Pakistan Journal of Agricultural Sciences, 44: 22-33

Pekar, S. 2005. Horizontal and vertical distribution of spiders (Araneae) in sunflowers. The Journal of Arachnology, 33: 197-204.

Rimbing, S., Memah, V. 2008. Jenis dan kelimpahan arthropoda predator pada beberapa habitat tanaman kedelai di Minahasa Utara. Journal Eugenia, 14: 436-444.

Rodrigues, E.N.L., Mendonca, M.S. Jr., Ott, R. 2009. Spider diversity in a rice agro-ecosystem and adjacent areas in southern Brazil. Revista Colombiana de Entomología, 35: 89-97.

Ruby, T., Rana, S.A., Rana, N., Inayat, T.P., Siddiqui,
M.J.I., Abbas, M.N. 2011. Weeds as viable habitat for arthropod species in crop lands of central Punjab. Pakistan Journal of Agriculture Sciences, 48: 145-152.

Rypstra, A.L., Carter, P.E., Balfourd, R.A., Marshall, S.D. 1999. Architectural features of agricultural habitats and their impact on the spiders inhabitants. Journal of Arachnology, 27: 371-377.

Samways, M. 1997. Classical biological control and biodiversity conservation: What risks are we prepared to accept? Biodiversity and Conservation, 6: $1309-1316$.

Suana, I.W.D., Solihin, D., Buchori, D., Manuwoto, S., Triwidodo, H. 2004. Komunitas laba-laba pada lansekap persawahan di Cianjur. Hayati, 11: 45-152.

Susilo, F.X. 2007. Pengendalian Hayati dengan Memberdayakan Musuh Alami Hama Tanaman. Yogyakarta: Graha Ilmu. xvi + 120. ISBN 978-979-756-229-8.

Symondson, W.O.C., Sunderland, K.D., Greenstone, M.H. 2002. Can generalist predators be effective biocontrol agents? Annual Review in Entomology, 47: 561-594.

Tikader, B.K. 1981. Fauna of India. Spiders, Heteropodidae and Clubionidae. Records of Zoological Survey of India. 3 pp, Ministry of Environment, Forest and Climate Change, Government of India, India.

Topping, C.J., Sunderland, K.D. 1992. Limitations to use of pitfall traps in ecological studies exemplified by a study of spiders in field of winter wheat. Journal of Applied Ecology, 29: 485-491.

Whitmore, C., Slotow, R., Crouch, T.E., DippenaarSchoeman, A.S. 2002. Diversity of spiders (Araneae) in a savanna reserve, northen province, South Africa. Journal of Arachnology, 30: 334-356.

Wise, D.H. 1993. Spiders in Ecological Webs. 328 pp., Cambridge University Press, Cambridge, UK. 